\title{
Quercetin Induces Hepatic Lipid Omega-Oxidation and Lowers Serum Lipid Levels in Mice
}

\author{
Elise F. Hoek-van den Hil ${ }^{1,2,3}$, Jaap Keijer ${ }^{1}$, Annelies Bunschoten ${ }^{1}$, Jacques J. M. Vervoort ${ }^{5}$, \\ Barbora Stankova ${ }^{4}$, Melissa Bekkenkamp', Laure Herreman', Dini Venema ${ }^{3}$, Peter C. H. Hollman ${ }^{3}$, \\ Eva Tvrzicka ${ }^{4}$, Ivonne M. C. M. Rietjens ${ }^{2}$, Evert M. van Schothorst ${ }^{1 *}$
}

1 Human and Animal Physiology, Wageningen University, Wageningen, The Netherlands, 2 Division of Toxicology, Wageningen University, Wageningen, The Netherlands, 3 RIKILT-Institute of Food Safety, Wageningen, The Netherlands, 4 4th Department of Internal Medicine, 1st Faculty of Medicine, Charles University, Prague, Czech Republic, $\mathbf{5}$ Laboratory of Biochemistry, Wageningen University, Wageningen, The Netherlands

\begin{abstract}
Elevated circulating lipid levels are known risk factors for cardiovascular diseases (CVD). In order to examine the effects of quercetin on lipid metabolism, mice received a mild-high-fat diet without (control) or with supplementation of $0.33 \%(w / w)$ quercetin for 12 weeks. Gas chromatography and ${ }^{1} \mathrm{H}$ nuclear magnetic resonance were used to quantitatively measure serum lipid profiles. Whole genome microarray analysis of liver tissue was used to identify possible mechanisms underlying altered circulating lipid levels. Body weight, energy intake and hepatic lipid accumulation did not differ significantly between the quercetin and the control group. In serum of quercetin-fed mice, triglycerides (TG) were decreased with $14 \%$ $(p<0.001)$ and total poly unsaturated fatty acids (PUFA) were increased with $13 \%(p<0.01)$. Palmitic acid, oleic acid, and linoleic acid were all decreased by $9-15 \%(p<0.05)$ in quercetin-fed mice. Both palmitic acid and oleic acid can be oxidized by omega $(\omega)$-oxidation. Gene expression profiling showed that quercetin increased hepatic lipid metabolism, especially $\omega-$ oxidation. At the gene level, this was reflected by the up-regulation of cytochrome P450 (Cyp) 4a10, Cyp4a14, Cyp4a31 and Acyl-CoA thioesterase 3 (Acot3). Two relevant regulators, cytochrome P450 oxidoreductase (Por, rate limiting for cytochrome P450s) and the transcription factor constitutive androstane receptor (Car; official symbol Nr1i3) were also upregulated in the quercetin-fed mice. We conclude that quercetin intake increased hepatic lipid $\omega$-oxidation and lowered corresponding circulating lipid levels, which may contribute to potential beneficial effects on CVD.
\end{abstract}

Citation: Hoek-van den Hil EF, Keijer J, Bunschoten A, Vervoort JJM, Stankova B, et al. (2013) Quercetin Induces Hepatic Lipid Omega-Oxidation and Lowers Serum Lipid Levels in Mice. PLoS ONE 8(1): e51588. doi:10.1371/journal.pone.0051588

Editor: Clarissa Menezes Maya-Monteiro, Fundação Oswaldo Cruz, Brazil

Received July 16, 2012; Accepted November 5, 2012; Published January 24, 2013

Copyright: (c) 2013 Hoek-van den Hil et al. This is an open-access article distributed under the terms of the Creative Commons Attribution License, which permits unrestricted use, distribution, and reproduction in any medium, provided the original author and source are credited.

Funding: The research is funded by the graduate school Voeding, Levensmiddelentechnologie, Agrobiotechnologie en Gezondheid (VLAG), and RIKILT-instutute of food safety. The funders had no role in study design, data collection and analysis, decision to publish, or preparation of the manuscript.

Competing Interests: The authors have declared that no competing interests exist.

*E-mail: evert.vanschothorst@wur.nl

\section{Introduction}

Cardiovascular diseases (CVD) are globally the most important cause of mortality. High consumption of fruits and vegetables are thought to be protective against GVD [1]. These protective effects have been suggested to be mediated by the flavonoid content of fruits and vegetables [2]. Various classes of flavonoids are common in plant foods, one being the flavonols. Quercetin is the major dietary flavonol in the Western diet, which is present in, for example, apples, tea, red wine and onions. Epidemiological studies have shown that the intake of this dietary flavonoid is associated with a reduction of GVD risk [3,4,5].

Elevated circulating levels of free fatty acids (FFA) and triglycerides (TG) are known risk factors for CVD [6,7,8,9]. In particular, increased levels of FFA and TG are associated with atherosclerosis, ischemic damage, pro arrhythmia, myocardial infarction, and heart failure. Accumulation of toxic lipid intermediates, suppression of glucose usage, or mitochondrial dysfunction potentially play a role in these effects [9]. Several studies showed that supplementation of quercetin to the diet decreased serum FFA and/or TG levels in rodents $[10,11,12]$. The cardio protective properties of quercetin may therefore be explained by the lipid lowering effect of quercetin. However, in these studies the FFA and TG levels were measured with enzyme-based assays. Recently, we have shown that flavonoids interfere with these enzymatic FFA and TG assays, which will lead to incorrect, apparently lower FFA and TG levels [13]. Therefore, it can be questioned whether quercetin has a true biological effect on lipid metabolism. Since various fatty acids are differently associated with CVD risk, it is also important to examine whether quercetin changes specific lipids [14]. Furthermore, based on gene expression analysis some genes have been put forward to explain the effects of quercetin on lipid metabolism [11,12], but these results are not conclusive. The aim of the present study was to reexamine the effects of quercetin on lipid metabolism, with state-ofthe-art analytical techniques, to exclude any interference of quercetin in the measeruments. Gas chromatography (GC) and a novel technique, ${ }^{1} \mathrm{H}$-nuclear magnetic resonance $\left({ }^{1} \mathrm{H}-\mathrm{NMR}\right)$ lipid profiling of mouse serum (based on $[15,16]$ ), were used to profile and quantify different serum lipids. In addition, whole genome microarray gene expression analysis of liver tissues was applied to unravel the possible underlying mechanisms. For this gene expression analysis the liver was chosen as target organ, since it is one of the major effector organs of lipid metabolism. This 

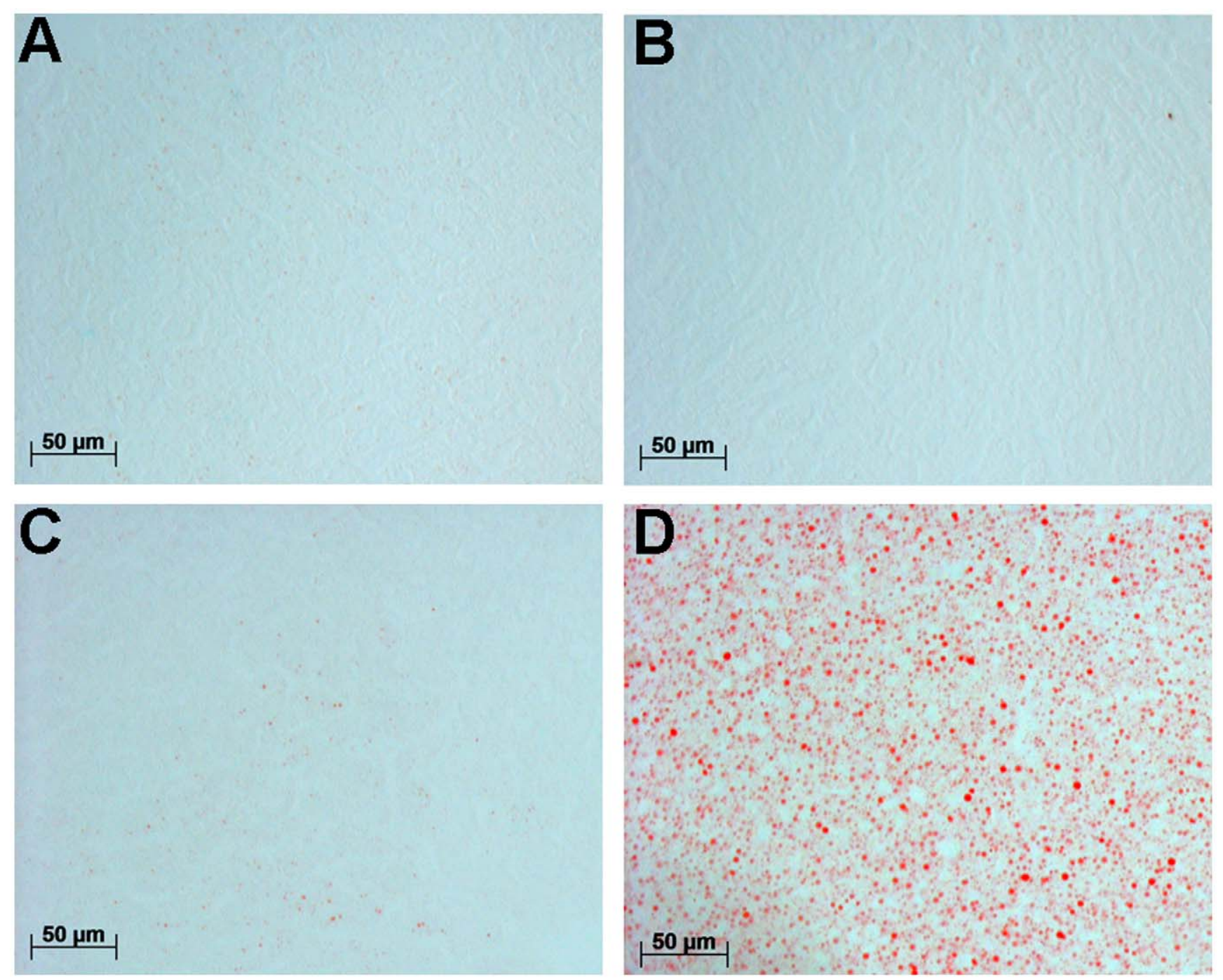

Figure 1. Representative pictures of hepatic lipid staining with Oil red $\mathbf{O}$. There were no significant differences in lipid accumulation between the control (A) and the quercetin (B) group. The lipid levels were comparable to mice fed a normal-fat diet (C) and much lower than the positive control of hepatic lipid accumulation from mice fed a high-fat diet (D). doi:10.1371/journal.pone.0051588.g001

principal combination of profiling of serum lipids and gene expression were used to investigate the mechanisms of action of quercetin on lipid metabolism.

The results show that a quercetin supplemented mild-high-fat diet in mice increased hepatic lipid metabolism, especially omega $(\omega)$-oxidation and reduced corresponding circulating lipid levels. These results contribute to the understanding of the protective properties of quercetin on CVD.

\section{Materials and Methods}

\section{Animals and Treatments}

Twenty-four male C57BL/6JOlaHsd mice (Harlan Laboratories, Horst, The Netherlands) were individually housed and maintained under environmentally controlled conditions (temperature $21^{\circ} \mathrm{C}, 12 \mathrm{~h} / 12 \mathrm{~h}$ light-dark cycle, $45 \%$ humidity). The mice had ad-libitum access to food and water. The food was a pelletized diet (Research Diets Services B.V., Wijk bij Duurstede, the Netherlands) with a mild-high-fat content of 30 energy \% (en \%). The fat content (en $\%$ and fat composition) corresponds to the average human intake in the Netherlands (Dutch Food Consumption Survey, 1998). The mice entered the experiment at 10 weeks of age. After two weeks of adaptation, the quercetin group $(\mathrm{n}=12)$ received the mild-high-fat diet supplemented with $0.33 \%(\mathrm{w} / \mathrm{w})$ quercetin (Sigma, Zwijndrecht, the Netherlands) for twelve weeks. The control group $(\mathrm{n}=12)$ was given the mild-high-fat diet without quercetin. The body weight and food intake of individual mice were monitored on a weekly basis. After 12 weeks of intervention all mice were fasted for two hours before anesthetisation by inhalation of $5 \%$ isoflurane. Blood was sampled via orbital extraction in collect serum tubes (Greiner Bio-one, Longwood, USA), which were centrifuged for $10 \mathrm{~min}$ at $3000 \mathrm{~g} 4^{\circ} \mathrm{C}$ to obtain serum, which was stored at $-80^{\circ} \mathrm{C}$. After blood collection, the mice were killed using cervical dislocation and the liver was dissected, weighted and snap frozen in liquid nitrogen and stored at $-80^{\circ} \mathrm{C}$. The experiment was performed according to the Dutch Animal Experimentation Act (1996) and the experimental protocol was approved by the Animal Welfare Committee of Wageningen University, Wageningen, The Netherlands (DEC 2007080). 


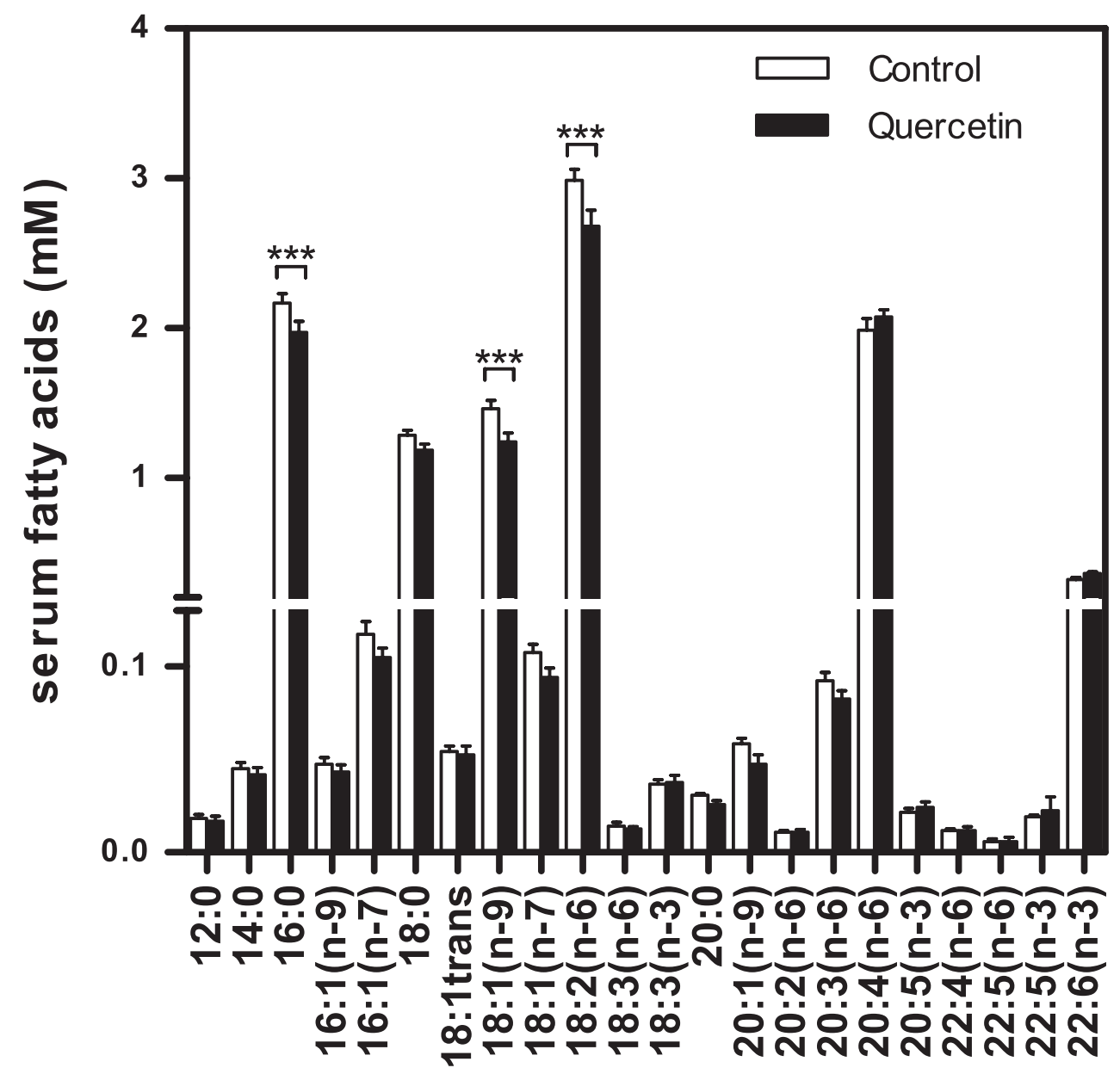

Figure 2. Cumulative serum profile of fatty acids originating from total lipids. Fatty acids were measured with GC. The levels of palmitic acid (16:0), oleic acid (18:1(n-9)), and linoleic acid (18:2(n-6)) were significant lower in the quercetin group. Data is presented as mean \pm SEM. Asterisks indicates a significant difference between the control and the quercetin group; ${ }^{* * *} p<0.001$.

doi:10.1371/journal.pone.0051588.g002

\section{HPLC Analysis of Quercetin Serum Levels}

HPLC with a coulometric array detector was used to measure the amount of quercetin in serum. For this $35 \mu \mathrm{l}$ of serum was hydrolyzed by incubation with $15 \mu \mathrm{l}$ of $12.5 \mathrm{mg} / \mathrm{ml} \beta$-glucuronidase/sulfatase in $0.5 \mathrm{M}$ sodium acetate $(\mathrm{pH}=5)$ with $5 \mathrm{~g} / \mathrm{l}$ ascorbic acid for two hours at $37^{\circ} \mathrm{C}$ to obtain deconjugated quercetin, isorhamnetin and tamarixetin. Subsequently, all samples were deproteinized by mixing with $100 \mu \mathrm{L}$ acetonitrile and $50 \mu \mathrm{L} 20 \% \mathrm{H}_{3} \mathrm{PO}_{4}$, with $3 \mathrm{~g} / \mathrm{L}$ ascorbic acid and centrifugation for $10 \mathrm{~min}$ at $13500 \mathrm{rpm}$ at $5^{\circ} \mathrm{C}$. Twenty $\mu$ l of the supernatant was analyzed on a HPLC system consisting of two pumps (model L2100; Hitachi, Tokyo, Japan), an autosampler (Model L-2200, Merck Hitachi), a CoulArray Module (Model 5600, ESA, Chelmsford, MA, USA) with electrochemical channels using carbon electrodes arranged in line and set to increasing specified potentials $(1=20 \mathrm{mV} ; 2=100 \mathrm{mV} ; 3=250 \mathrm{mV} ; 4=500 \mathrm{mV})$ and a thermostatic column/cell chamber set at $30^{\circ} \mathrm{C}$. The chromatography was performed on a Platinum C18 column (EPS; $150 \times 4.6 \mathrm{~mm}, 3 \mu$, Grace Davison Sciences, Deerfield, IL, USA) equipped with a MPLC Newguard precolumn (Brownlee RP18 $7 \mu \mathrm{m} 15 \times 3.2$ mm, Perkin Elmer, Shelton, CT, USA), using a gradient elution with two mobile phases. Mobile phase A consisted of $15 \%$ acetonitrile in $25 \mathrm{mM} \mathrm{H}_{3} \mathrm{PO}_{4}$ buffer (pH 2.4). Mobile phase $\mathrm{B}$ consisted of $50 \%$ acetonitrile in $25 \mathrm{mM} \mathrm{H}_{3} \mathrm{PO}_{4}$ buffer ( $\mathrm{pH}$ 2.4). The gradient, at a flow rate of $1.0 \mathrm{ml} / \mathrm{min}$, was as follows: 0-20 min, linear gradient from $0 \%$ to $100 \%$ mobile phase $\mathrm{B} ; 20-22 \mathrm{~min}$, isocratic at $100 \% \mathrm{~B} ; 22-30 \mathrm{~min}$, linear return from 100 to $0 \% \mathrm{~B}$; the total runtime was $30.0 \mathrm{~min}$. Quercetin, isorhamnetin and tamarixetin were quantified using calibration curves made with commercially available standards.

\section{Hepatic Lipid Staining with Oil Red O}

Frozen liver sections $(7 \mu \mathrm{m})$ were fixed with $3.7 \%$ buffered formalin. Neutral lipids were stained with Oil red O (Sigma). The stained areas were quantified based on a described method [17] using Photoshop software (version 12.0.4, Adobe). Briefly, contrast was enhanced with automatic contrast tool, red pixels were selected with the colour range selecting tool, and total selected area was measured in $\mu \mathrm{m}^{2}$. Ten to 16 pictures per animal were quantified $(n=6-8)$. Controls of hepatic lipid accumulation were liver of C57BL/6JOlaHsd mice fed a normal-fat diet (10 en \% of fat) or a high-fat diet (40 en $\%$ of fat) for twelve weeks.

\section{Serum Lipid Analysis with Enzymatic Assays}

FFA assay (Wako NEFA-HR(2) kit, Sopachem BV, Ochten, The Netherlands) and TG assay (TG liquicolor kit, Human, Wiesbaden, Germany) were performed as described previously [13]. 
Table 1. Fatty acid composition of the control and quercetin diet in percentages.

\begin{tabular}{|c|c|c|}
\hline Lipids & Control diet (\%) & Quercetin diet (\%) \\
\hline $\mathrm{C} 12: 0$ & 0.09 & 0.08 \\
\hline C14:0 & 1.11 & 1.09 \\
\hline C14:1 & 0.06 & 0.06 \\
\hline C15:0 & 0.08 & 0.08 \\
\hline C16:0 & 22.40 & 22.26 \\
\hline C16:1 & 1.25 & 1.25 \\
\hline $\mathrm{C} 17: 0$ & 0.30 & 0.30 \\
\hline C17:1 & 0.19 & 0.15 \\
\hline C18:0 & 10.79 & 10.87 \\
\hline C18:1 trans & 0.46 & 0.47 \\
\hline C18:1 & 33.87 & 33.94 \\
\hline C18:1 & 1.60 & 1.61 \\
\hline C18:2 & 24.23 & 24.21 \\
\hline$C 18: 3(n-6)$ & 0.01 & 0.01 \\
\hline C18:3 & 0.71 & 0.72 \\
\hline$C 20: 0$ & 0.23 & 0.22 \\
\hline C20:1 & 0.55 & 0.56 \\
\hline$C 20: 2$ & 0.29 & 0.30 \\
\hline$C 20: 3(n-6)$ & 0.05 & 0.05 \\
\hline $\mathrm{C} 22: 0$ & 0.06 & 0.06 \\
\hline$C 20: 3(n-3)$ & 0.20 & 0.20 \\
\hline $\mathrm{C} 24: 0$ & 0.06 & 0.06 \\
\hline$C 22: 5(n-3)$ & 0.00 & 0.07 \\
\hline$C 22: 6(n-3)$ & 0.02 & 0.03 \\
\hline Saturated FA & 35.12 & 35.02 \\
\hline MUFA & 37.98 & 38.04 \\
\hline PUFA & 25.51 & 25.59 \\
\hline
\end{tabular}

doi:10.1371/journal.pone.0051588.t001

\section{Serum Fatty Acid Analysis with GC}

Total serum fatty acids were extracted from $50 \mu \mathrm{l}$ serum as described [18], using dichloromethane instead of chloroform [19]. Ten $\mu \mathrm{g}$ of nonadecanoic acid methyl ester (NuCheck Prep, USA) was added to each sample before extraction, as an internal standard. Samples were transmethylated to fatty-esther methyl esthers (FAME) by incubation in $1 \mathrm{M}$ sodium methoxide in dry methanol for $20 \mathrm{~min}$ at $80^{\circ} \mathrm{C}$. The reaction mixture was then cooled, acidified with 98\% sulphuric acid and incubated for 1 hour at room temperature to methylate free acids. Lipid methyl esters were extracted with hexane, and the hexane extracts were subsequently dried under a nitrogen flow. Next, the residue was dissolved in $100 \mu \mathrm{l}$ of $\mathrm{n}$-heptane and stored at $-20^{\circ} \mathrm{C}$ under nitrogen until analysed. All reactions were performed under nitrogen atmosphere. GC was performed with a Trace-GG gas chromatograph combined with AS 2000 autosampler (ThermoFinnigan, USA), equipped with a capillary split/splitless injector and a flame ionization detector. Analyses of FAME were performed on a fused-silica capillary column coated with chemically bond stationary phase CP-Sil $88 \mathrm{CB}$ (100 m, $0.32 \mathrm{~mm}$ I.D.). The oven temperature was programmed as follows: from $80^{\circ} \mathrm{C}$ to $260^{\circ} \mathrm{C}$ at $2^{\circ} \mathrm{C} / \mathrm{min}$, then to $280^{\circ} \mathrm{C}$ at $10^{\circ} \mathrm{C} / \mathrm{min}$, where it was maintained for $45 \mathrm{~min}$. The injector and detector temperatures were set at $250^{\circ} \mathrm{C}$ and $270^{\circ} \mathrm{C}$, respectively. Hydrogen carrier gas was maintained at a head pressure of $70 \mathrm{kPa}$ and total flow of $44 \mathrm{ml} / \mathrm{min}$, with a split ratio of 1:35. Integration software Clarity version 2.4.1.57 (Data Apex Ltd. Prague, Czech Rep.) was used for data acquisition and handling.

\section{Serum Lipid Analysis with ${ }^{1} \mathrm{H}-\mathrm{NMR}$}

Total serum lipids were extracted from $20 \mu \mathrm{l}$ of blood serum as described [18] based on $[15,16]$ with some adaptations to optimise the protocol. Briefly, $20 \mu \mathrm{l}$ of $150 \mathrm{mM}$ sodium phosphate buffer with $0.04 \%$ azide $(\mathrm{pH}=3)$ was added per serum sample. Then $900 \mu \mathrm{l}$ chloroform:methanol $(2: 1) \mathrm{v} / \mathrm{v}$ and $900 \mu \mathrm{l} 0.15 \mathrm{M} \mathrm{NaCl}$ $(\mathrm{pH}=3)$ were added to the sample. Samples were shaken for 5 minutes on a horizontal shaker and centrifuged for 10 minutes at $4500 \mathrm{~g}$ to separate the organic and water phase. The lower organic phase was recovered and the aqueous layer was extracted

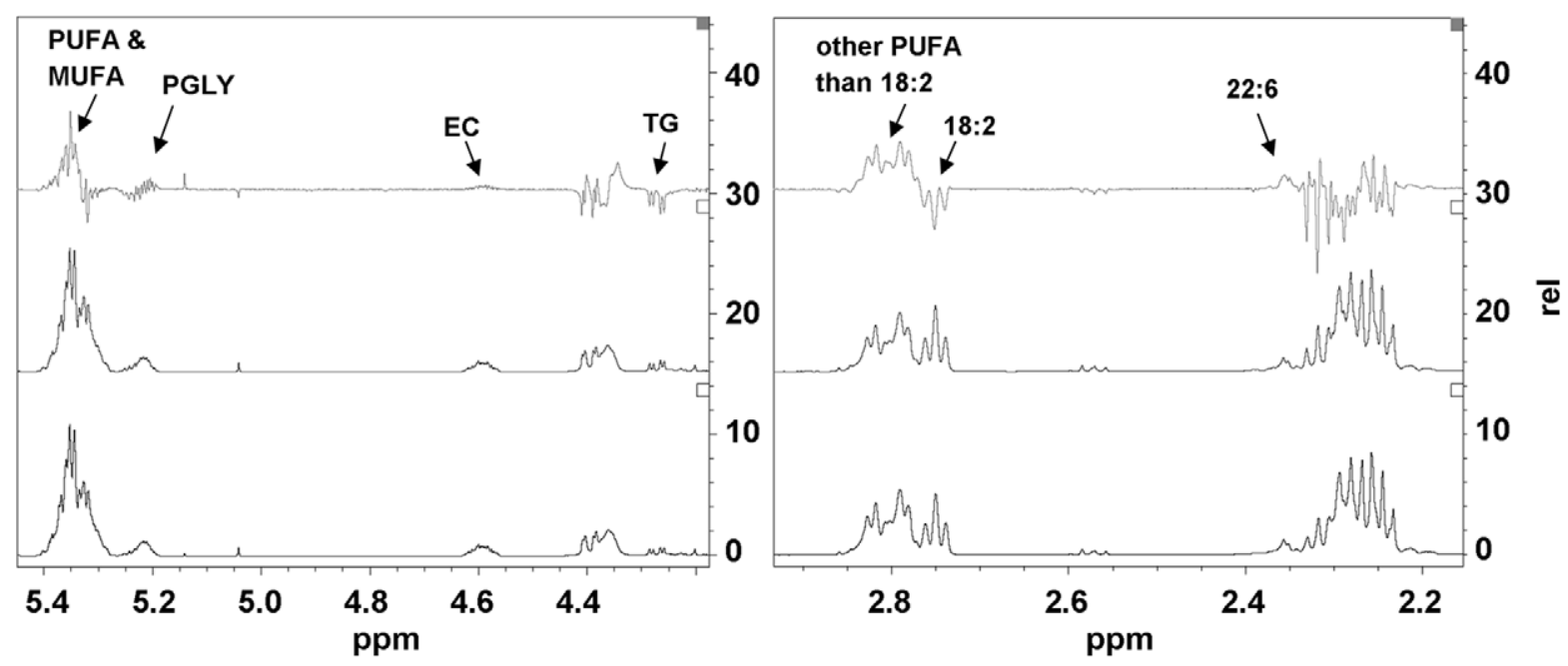

Figure 3. ${ }^{1} \mathrm{H}$ NMR difference spectrum of the quercetin-fed mice minus the control mice. Serum samples from mice exposed to quercetin minus the ${ }^{1} \mathrm{H}$ NMR spectra of the sera from control mice is represented by the top line. The control group is represented by the middle line and the quercetin group is represented by the lowest line. Two representative parts of the spectrum are presented in the figure. PUFA, poly unsaturated fatty acids; MUFA, mono unsaturated fatty acids; FA, fatty acids; TG, triglycerides; PGLY, phosphoglycerides; PC phosphatidylcholine; EC, esterified cholesterol; TC total cholesterol. doi:10.1371/journal.pone.0051588.g003 


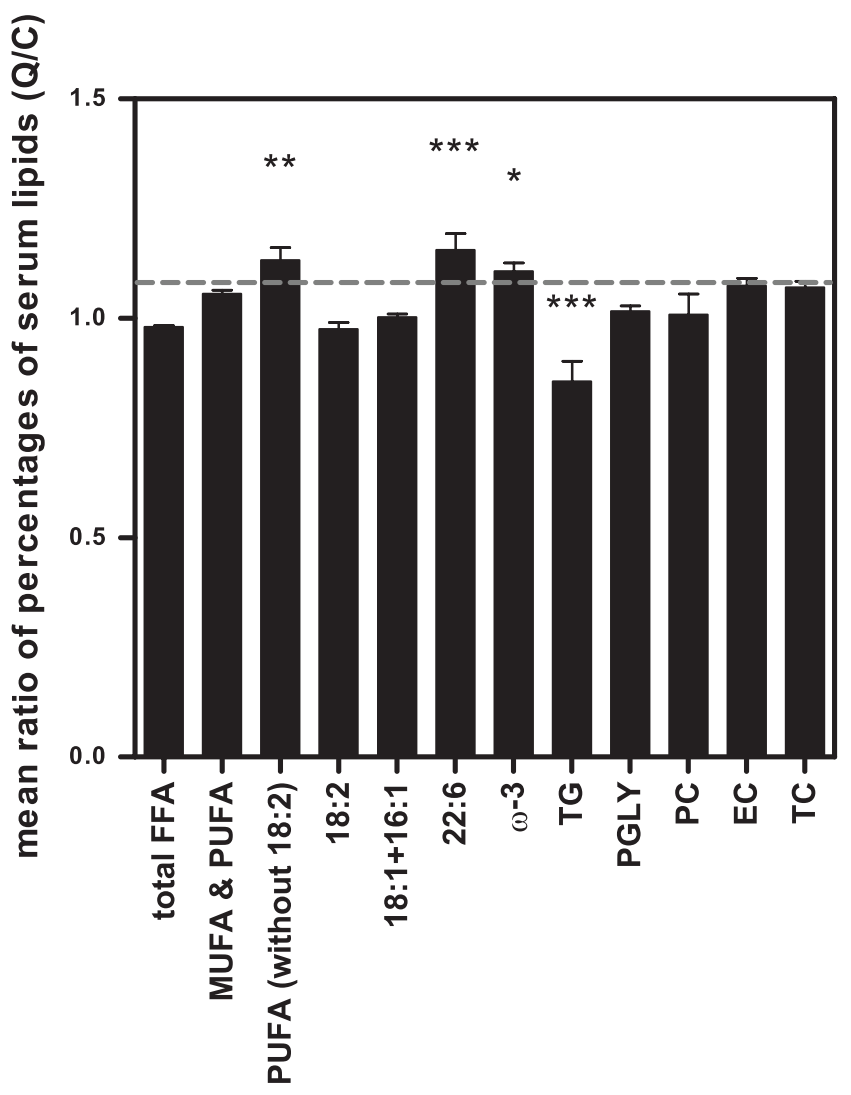

Figure 4. Percentages of lipids present in serum per mouse plotted for quercetin mice to control mice. Lipids were measured with ${ }^{1} \mathrm{H}$ NMR. Data is presented as the mean ratio of percentages of lipids present in serum per mouse plotted for quercetin-fed $(Q)$ mice over control (C) mice. Total FFA were not changed, while other PUFA than 18:2 FA, 22:6 FA, and, w-3 FA were significantly increased. TG were significantly decreased by the quercetin diet. Data is presented as mean \pm SEM. Asterisks indicates a significant difference between the control and the quercetin group; ${ }^{*} p<0.05,{ }^{* *} p<0.01,{ }^{* *} p<0.001$. PUFA, poly unsaturated fatty acids; MUFA, mono unsaturated fatty acids; FA, fatty acids; TG, triglycerides; PGLY, phosphoglycerides; PC phosphatidylcholine; EC, esterified cholesterol; TC total cholesterol.

doi:10.1371/journal.pone.0051588.g004

again with $500 \mu \mathrm{l}$ chloroform. The collected organic layers were combined and evaporated to dryness using argon. The samples were vacuum and freeze dried and dissolved in chloroform containing $0.03 \%$ tetramethylsilane. ${ }^{1} \mathrm{H}$ NMR was measured on a Bruker AVANCE spectrometer operating at $600 \mathrm{MHz}$. For each spectrum 256 (Free induction decays (FID)) transients were collected with a flip angle of $90^{\circ}$, with an acquisition time of $1.82 \mathrm{~s}$, a relaxation delay of $4 \mathrm{~s}$, a spectral width of $30 \mathrm{ppm}$ and a standard noesy $1 \mathrm{D}$ pulse sequence, at $25^{\circ} \mathrm{C}$, and four dummy scans were used. The FID with $64 \mathrm{~K}$ data points were once zerofilled and multiplied by an exponential window function with a $0.2 \mathrm{~Hz}$ Line-broadening before a subsequent Fourier transformation. To all spectra a baseline correction was applied and the spectra were aligned on the chloroform peak at $7.24 \mathrm{ppm}$.

The nature of the various resonances was based on the ${ }^{1} \mathrm{H}$ NMR spectra as reported $[15,16]$. The regions selected to quantify the different lipid fractions were as follows; TG (4.300$4.250 \mathrm{ppm})$, total FFA (1.380-1.198 ppm), mono unsaturated fatty acids (MUFA) and PUFA $(-\mathrm{CH}=\mathrm{CH}-)(5.41$ to $5.27 \mathrm{ppm})$, other PUFA than 18:2 FA (2.862-2.768 ppm), 18:2 FA including linoleic acid (18:2(n-6)) (2.767-2.721 ppm), 18:1 and 16:1 FA

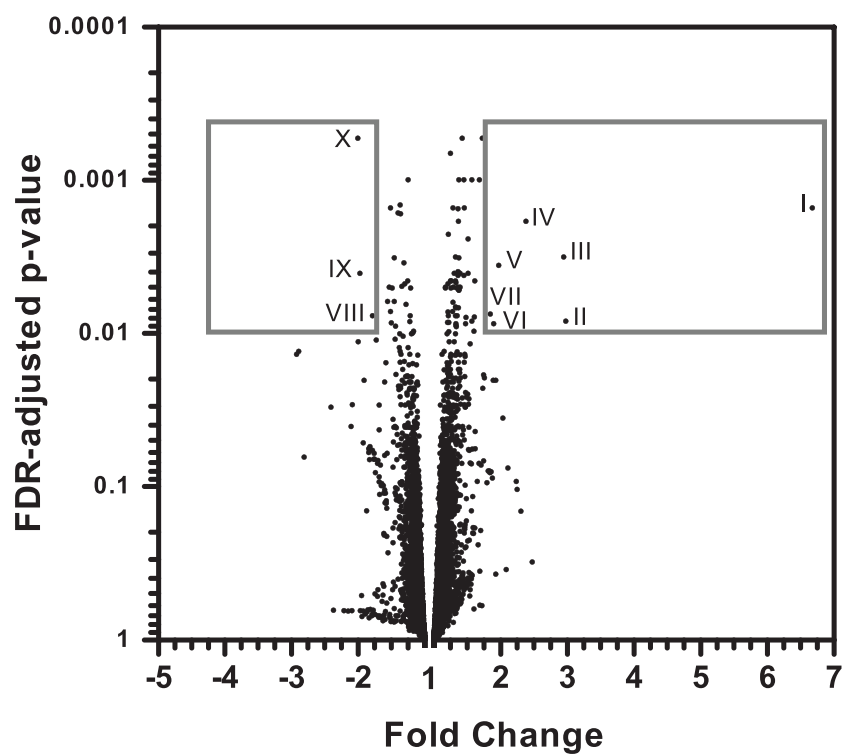

Figure 5. Volcano plot of all expressed probes by global hepatic gene expression analysis. Volcano plot of all probes showing statistics FDR-adjusted $p$-values plotted against the fold change of each probe (quercetin vs. control). Frames outline genes that are regulated with absolute fold change $>1.75$ and a FDR-adjusted $p$ value $<0.01$; these gene symbols, names and functions are also represented in table 1 .

doi:10.1371/journal.pone.0051588.g005

including oleic acid (18:1(n-9)) (2.050-2.011 ppm), 22:6 FA including docosahexaenoic acid (22:6(n-3)) (2.379-2.342 ppm), $\omega$-3 FA (0.957-0.947 ppm), phophoglycerides (PGLY) (5.258$5.190 \mathrm{ppm}$ ), phosphatidylcholine (PG) (3.787-3.738 ppm), esters of cholesterol (EG) (4.651-4.539 ppm) and total cholesterol (TC) (0.902-0.895 ppm).

\section{Fatty Acid Composition of Diets}

Fatty acids from the diets were extracted with accelerated solvent extraction according to the manufacturer's protocol (Thermo Scientific) and dissolved in toluene. Subsequently, toluene was evaporated under nitrogen at $40^{\circ} \mathrm{C}$ and fatty acids were dissolved in iso-octane $(5 \mathrm{ml})$ and $200 \mu \mathrm{l} 2 \mathrm{M} \mathrm{KOH}$ in methanol was added and the mixture was shaken for one minute. For neutralization, $\mathrm{NaHSO}_{4}$ was added and samples were shaken for 1 minute. The iso-octane fraction $(1 \mu \mathrm{l})$ was injected in the gas chromatograph equipped with a capillary split injector (split ratio $1: 40)$ and flame ionization detector. Analyses were performed on a CP select column for FAME $(50 \mathrm{~m} \times 0.25 \mathrm{~mm}$ ID). The oven temperature was programmed from $100^{\circ} \mathrm{C}$ to $230^{\circ} \mathrm{C}$ at $6^{\circ} \mathrm{C} / \mathrm{min}$.

\section{RNA Isolation}

For RNA isolation, liver was homogenized in liquid nitrogen, total RNA was isolated using TRIzol reagent (Invitrogen, Breda, The Netherlands) followed by purification with RNeasy columns (Qiagen, Venlo, The Netherlands). RNA concentration and purity were measured using a Nanodrop spectrophotometer (IsoGen Life Science, Maarsen, The Netherlands); all RNA samples were of high purity. RNA quality was additionally checked on the Experion automated electrophoresis system (Bio-Rad, Veenendaal, The Netherlands).

\section{Microarray Analysis}

For global transcriptome analysis of liver samples, $4 \times 44 \mathrm{~K}$ Agilent whole-mouse genome microarrays (G4122F, Agilent 
Table 2. Regulated hepatic genes with an absolute fold change $>1.75$ and FDR-adjusted $p$-value $<0.01$.

\begin{tabular}{|c|c|c|c|c|}
\hline Gene Symbol & Gene Name & Fold Change & $\begin{array}{l}\text { FDR adjusted } \\
\text { p-value }\end{array}$ & Function \\
\hline I. Cyp4a14 & Cytochrome P450 4a14 & 6.68 & 0.0015 & $\omega$-oxidation of medium-chain fatty acids \\
\hline II. Сур4а10 & Cytochrome P450 4a10 & 2.98 & 0.0083 & $\omega$-oxidation of medium-chain fatty acids \\
\hline III. Usp2 & Ubiquitin specific peptidase 2 & 2.95 & 0.0032 & $\begin{array}{l}\text { regulation of intracellular protein breakdown, cell cycle regulation and } \\
\text { stress response }\end{array}$ \\
\hline IV. Acot3 & Acyl-CoA thioesterase 3 & 2.38 & 0.0018 & $\begin{array}{l}\text { catalysator of hydrolysis of acyl-CoAs (C12-C16) after } \omega \text {-oxidation to FFA } \\
\text { and coenzyme A }\end{array}$ \\
\hline V. Por & P450 (cytochrome) oxidoreductase & 1.97 & 0.0036 & $\begin{array}{l}\text { electron donor for the microsomal cytochrome P450 mixed-function } \\
\text { oxidase system }\end{array}$ \\
\hline VI. Сур4а31 & Cytochrome P450 4a31 & 1.90 & 0.0086 & $\omega$-oxidation of medium-chain fatty acids \\
\hline VII. Coq10b & Coenzyme Q10 homolog B & 1.85 & 0.0074 & $\begin{array}{l}\text { an essential electron carrier and proton translocator in the mitochondrial } \\
\text { respiratory chain }\end{array}$ \\
\hline VIII. Insig2 & Insulin-induced gene 2 & -1.78 & 0.0076 & lipid and cholesterol metabolic process \\
\hline IX. Spon2 & Spondin 2, extracellular matrix protein & $n-1.98$ & 0.0040 & essential in the initiation of the innate immune response \\
\hline X. Chka & Choline kinase alpha & -2.00 & 0.0005 & phosphatidylcholine biosynthesis \\
\hline
\end{tabular}

Technologies Inc., Santa Clara, CA) were used. Preparation of the samples and the microarray hybridizations were carried out according to the manufacturer's protocol with a few modifications as described previously [20]. All materials and reagents were from Agilent Technologies, Palo Alto, USA unless stated otherwise. Briefly, cDNA was synthesized for each animal from $1 \mu \mathrm{g}$ RNA using the Agilent Low-RNA Input Fluorescent Linear Amplification Kit without addition of spikes. Thereafter, samples were split
Cyp4a14

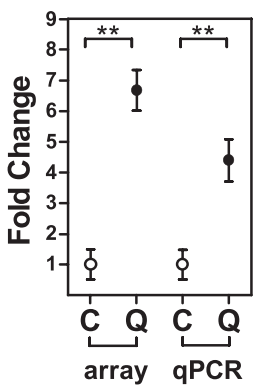

Por

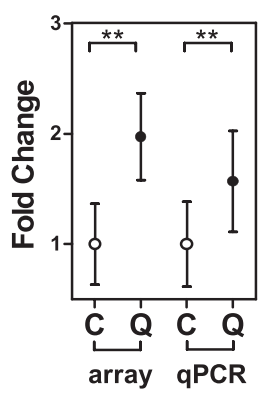

Cyp4a10

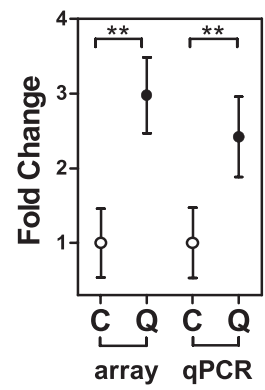

Car

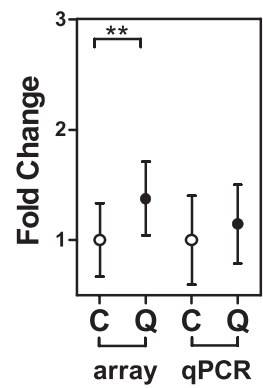

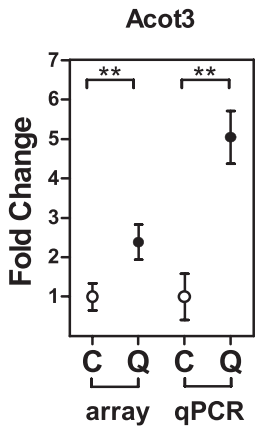

Figure 6. Microarray confirmation by RT-qPCR. The quercetin (Q) regulated genes Cyp4a14, Cyp4a10, Acot3, Car (Nr1i3) and Por, compared to the control (C) found by microarray analysis were confirmed with RT-qPCR. Data is presented as mean \pm SEM $(n=12)$. Asterisks indicates a significant difference between the control and quercetin group; ${ }^{* *} p<0.01$.

doi:10.1371/journal.pone.0051588.g006 into two equal amounts, to synthesize Cyanine 3-CTP (Cy3) and Cyanine 5-CTP (Cy5) labelled cRNA, using half the amounts per dye as indicated by the manufacturer. Labelled cRNA was purified using RNeasy columns (Qiagen). All samples had a cRNA yield higher than $825 \mathrm{ng}$ and a specific activity of at least 8.0 pmol Cydye per $\mu \mathrm{g}$ cRNA. Cy3-labeled cRNA samples were pooled on an equimolar basis and used as a common reference pool. Individual

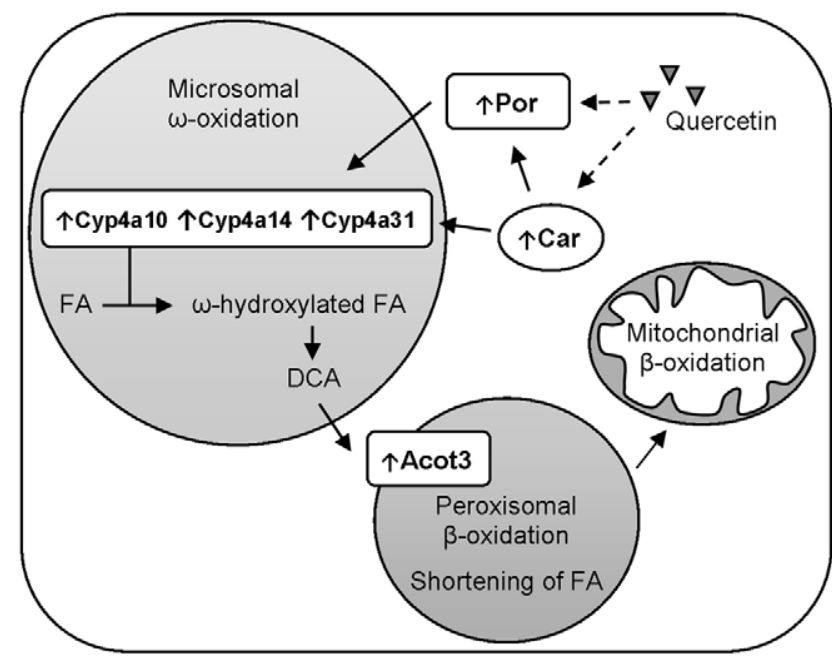

Figure 7. Schematic representation of the quercetin-regulated genes involved in $\omega$-oxidation. Microarray and RT-qPCR analysis showed an up regulation of Cyp4a14, Cyp4a10, Acot3, Por and Car. Quercetin is suggested to activate Car and/or Por (dashed arrow). Activation of the transcription factor CAR can induce the microsomal cytochrome P450 enzymes, CYP4a14, CYP4a10 and CYP4a31, which are important enzymes involved in $\omega$-oxidation. POR is the electron donor for the microsomal cytochrome P450 mixed-function oxidase system. Formed DCA by $\omega$-oxidation are further degraded by peroxisomal $\beta$ oxidation to shorter chain fatty acids. ACOT3 is involved in the transport of DCA into the peroxisomes by hydrolysis of long-medium chain fatty acyl-CoA esters to FFA, which can be further transported out of peroxisomes to mitochondria for $\beta$-oxidation or excreted in the urine. FA, fatty acids; DCA, dicarboxylic acids. doi:10.1371/journal.pone.0051588.g007 
825-ng Cy5-labeled cRNA and 825-ng pooled Cy3-labeled cRNA were fragmented in $1 \times$ fragmentation and $1 \times$ blocking agent at $60^{\circ} \mathrm{C}$ for $30 \mathrm{~min}$ and thereafter mixed with GEx hybridization buffer (HI-RPM) and hybridized in a $1: 1$ ratio at $65^{\circ} \mathrm{C}$ for $17 \mathrm{~h}$ in the Agilent Microarray Hybridization Chamber rotating at $10 \mathrm{rpm}$. After hybridization, slides were washed according to the manufacturers' wash protocol. Arrays were scanned with an Agilent scanner with 10 and $100 \%$ laser-power intensities.

\section{Normalisation and Microarray Data Analysis}

Signal intensities for each spot were quantified using Feature Extraction version 9.1 (Agilent Technologies). Median density values and background values of each spot were extracted for both the experimental samples (Cy5) and the reference samples (Cy3). Quality control for every microarray was performed visually by using 'Quality control graphs' from Feature extraction and M-A plots and box plots, which were made using limmaGUI in $\mathrm{R}$ (Bioconductor, Wettenhal, 2004). Data were imported into GeneMaths XT 2.0 (Applied Maths, Sint-Martens-Latem, Belgium). Spots with an average Cy5 and Cy3 signal twice above background were considered expressed and $\log$ transformed. The Cy5 signal was normalized against the Cy3 intensity as described before [21]. Pathway analysis was performed using MetaCore (GeneGo, St. Joseph, Michigan, USA) and Ingenuity Systems (Ingenuity, Redwood City, California, USA). Fold change was expressed as the ratio of the quercetin group versus the control group. Microarray data has been deposited in NCBI Gene Expression Omnibus (GEO) under accession number GSE39140.

\section{Real Time Quantitative Polymerase Chain Reaction (RT- $\mathrm{qPCR})$}

RT-qPCR was performed using the RNA of the liver samples to validate the microarray data. One microgram of RNA of all individual samples was used for cDNA synthesis using the iScript cDNA synthesis kit (Bio-Rad). RT-qPGR reactions were performed with iQ SYBR Green Supermix (Bio-Rad) using the MyIQ single-colour real-time PCR detection system (Bio-Rad). Individual samples were measured in duplicate. Data were normalized against reference genes beta-2 microglobulin (B2m) and hypoxanthine phophoribosyltransferase 1 (Hprtl) which were chosen based on stable gene expression levels (geNorm, Ghent University Hospital, Ghent, Belgium) and the microarray data. Primers were designed using the NCBI Primer-Blast (NCBI Web site). Sequences of the used primes were as follows: cytochrome $\mathrm{P} 450$ 4al4 (Cyp4a14); 5' -TTGTTTCGCGTGCGGAATGG-3' and 5'CACTCGATCTGTGTGCTCGTGA-3' ${ }^{\prime}$, cytochrome P450 4a 10 (Cyp4a10); 5'-TCTACCCACGTGTCGCAGGC-3' and 5'ACACGTCTGGATTTGGCGACA-3', acyl-CoA thioesterase 3 (Acot3); 5'-GCTGTGACGTACGTGCTCAGTCA-3' and 5'ATATAGAGCGATTGATGATGACAGGGG-3', cytochrome P450 oxidoreductase (Por); 5'-CGAGGGGAAGGAGCTGTACG-3' and 5'-CACAGGTGGTGGATGGGTGG-3', constitutive androstane receptor (Car; official gene symbol Nrli3); 5'CGGTGTTGCCTCTGCTCACA-3' and 5'-GGTTAGGGACGGGAAGAGCG - $3^{\prime}$, beta-2-microglobulin (B2m); $5^{\prime}-$ CGCGACTGAGACTGATACATACGC-3' and ${ }^{\prime}{ }^{\prime}$ AGAAACTGGATTTGTAATTAAGCAGGTTC-3', hypoxanthine-guanine phosphoribosyltransferase (Hprt1); 5'-TGACACTGGTAAAACAATGCAAACTTTG- ${ }^{\prime}$ and $5^{\prime}-$ GAGGTCGTTTTCACGAGCAAGCT - $3^{\prime}$.

\section{Statistical Analysis}

For microarray analysis, Student's $t$ tests were used with false discovery rate (FDR) adjustment for multiple testing correction according to Benjamini-Hochberg [22]. GraphPad Prism version 5.03 (Graphpad Software, San Diego, USA) was used for other statistical analysis, with Student's $t$ test being used to compare the two groups. Two-way ANOVA was used for analysis of the lipid profiles in serum and diets, followed by a Bonferroni post hoc test. P-values smaller than 0.05 were considered statistically significant.

\section{Results}

\section{Body Weight, Energy Intake and Quercetin Uptake}

Body weight (BW) and energy intake of the adult male mice, which were fed a mild-high-fat diet with or without quercetin supplementation, were not significantly different between the quercetin and the control group during all 12 weeks. Final body weight was $27.9 \pm 1.9$ and $28.5 \pm 1.6$ (mean \pm SD) gram, and cumulative total energy intake was $4580 \pm 172$ and $4636 \pm 207 \mathrm{~kJ}$ for the quercetin and control group, respectively.

The calculated quercetin intake for the quercetin-fed mice was $\sim 400 \mathrm{mg} / \mathrm{kg} \mathrm{BW} /$ day. The sum of quercetin and isorhamnetin after deconjugation in serum was $13.5 \pm 3.1 \mu \mathrm{M}$ expressed as aglycone (quercetin was $6.7 \pm 0.9 \mu \mathrm{M}$, isorhamnetin was $6.8 \pm 2.6 \mu \mathrm{M}$, and no tamarixetin was found). No quercetin was found in serum of the control animals.

Relative liver weight was significantly lower in the quercetin-fed mice $(3.80 \% \pm 0.20 ; \mathrm{p}=0.007)$ compared to the control mice $(4.08 \% \pm 0.26)$, while no significant differences were found for other organs, including white adipose tissue, brown adipose tissue, lung, heart, muscles (data not shown). Hepatic lipid staining showed no significant differences between the quercetin and control group (Figure 1a and b); the Oil red $\mathrm{O}$ recorded areas were $480 \pm 493 \mu \mathrm{m}^{2}$ and $321 \pm 440 \mu \mathrm{m}^{2}$, respectively. The hepatic lipid levels were much lower than a positive control of hepatic lipid accumulation $\left(13,151 \pm 4,410 \mu^{2}\right)$ and in the same range of hepatic lipid levels found in liver of mice fed a normal-fat diet $\left(516 \pm 271 \mu^{2}\right.$ ) (Figure 1c and d).

\section{Serum Lipids as Determined by Enzymatic Assays}

Quantification of serum FFA and TG levels was performed using the enzymatic FFA and TG assays, which showed a significant decrease of $13 \%$ FFA $(p<0.05)$ and $27 \%$ TG $(p<0.05)$ due to the quercetin diet. However, since quercetin has been shown to interfere with these enzymatic assays resulting in incorrect, apparently lower FFA and TG levels [13], two additional analytical techniques were applied to assess serum lipid profiles, and to check if the decreased FFA and TG levels detected by the enzymatic assays represent real biological effects.

\section{Serum Fatty Acid Profile as Determined by GC}

GC fatty acid profiles reveales fatty acids originating from TG, FFA, cholesteryl esters and phospholipids. The serum fatty acid profile showed a total decrease of $7 \%(\mathrm{p}<0.001)$ in the quercetinfed mice. The levels of palmitic acid (16:0), oleic acid (18:1(n-9)) and linoleic acid $(18: 2(n-6))$ were $9-15 \%$ lower $(p<0.001)$ in the quercetin group (Figure 2). These are the main fatty acids in the quercetin diet and the control diet, which were similar in terms of fatty acid composition (Table 1). All other fatty acids that were present in the serum showed a tendency of decreased levels due to the quercetin treatment, except for some poly unsaturated fatty acids (PUFA), such as arachidonic acid (20:4(n-6)) and docosahexaenoic acid (22:6(n-3)) which were slightly, but non significantly, increased in the serum of quercetin-supplemented mice. 


\section{Serum Lipid Profile as Determined by ${ }^{1} \mathrm{H}$ NMR}

${ }^{1} \mathrm{H}$ NMR measurement reveals total TG, FFA, cholesterol and phospholipids that are present in serum, separately. Figure 3 presents the ${ }^{1} \mathrm{H}$ NMR difference spectrum, that is composed of the ${ }^{1} \mathrm{H}$ NMR spectra of serum samples from mice exposed to quercetin $(\mathrm{n}=12)$ minus the ${ }^{1} \mathrm{H}$ NMR spectra of the sera from control mice $(n=12)$. The different regions (based on $[15,16]$ ) were selected to obtain information on several subsets of FFA and/ or TG, as shown in Figure 3. Integration of the respective peak areas in the ${ }^{1} \mathrm{H}$ NMR spectra of the individual serum samples resulted in the amounts of the various lipids. The data are presented in figure 4 as the mean ratio of percentages of lipids present in serum of quercetin-fed mice as compared to control mice. From these data it follows that upon quercetin exposure the levels of TG are significantly decreased with $14 \%(p<0.001)$, while some specific poly unsaturated FFA levels were increased with $11-$ $16 \%$; these were PUFA other than 18:2 FA $(\mathrm{p}<0.01), 22: 6 \mathrm{FA}$ $(p<0.001)$, and $\omega-3$ FA $(p<0.05)$. The total amount of FFA was the same in both groups, the levels of PGLY and PC showed no change and the EC and TC showed a slight increase, although not significant. This implies that the overall decrease in lipid levels that are observed in the GC analysis are due to a decrease in TG.

\section{Quercetin Altered the Expression of Genes Involved in Lipid Metabolism}

Gene expression was analysed using whole genome gene expression microarrays. Of the 23,256 probes being expressed, 415 probes were significantly differently expressed by quercetin treatment $(\mathrm{p}<0.05$, FDR-adjusted). Regulation of lipid metabolism by quercetin was found by pathway analysis of the differently expressed genes using the two major analysis programs, Metacore and Ingenuity. 'Phospholipid metabolism' was the most significantly regulated pathway in Metacore with a p-value of 4.8E-05 (with 3 down-regulated and 1 up-regulated gene out of 33 genes). Ingenuity pathway analyses identified: 'LPS/IL-1 Mediated Inhibition of RXR Function' as the most regulated pathway (pvalue of $5.46 \mathrm{E}-05$, with 13 up-regulated genes out of 187). In this pathway Car is the central transcription factor and the genes, in particular cytochromes P450, overlap partly with the 'linoleic acid pathway', which is the number 3 pathway ( $\mathrm{p}$-value of $1.7 \mathrm{E}-03$ with 4 up-regulated genes out of 83 genes) in Metacore. Although, in each of these pathways a relative small number of genes were regulated out of the total number of genes present, it was clear that these regulated genes corresponded with the top significantly regulated genes. The ten most regulated genes (absolute fold change $>1.75$ and a FDR adjusted $p$-value $<0.01$ ), where almost all involved in lipid metabolism, particularly in $\omega$-oxidation of fatty acids (Figure 5, table 2). These genes involved in $\omega$-oxidation included Cyp4a14, Cyp4a10, Cyp4a31, Acot3 and Por. Altogether, lipid metabolism, and in particular $\omega$-oxidation, were identified as being regulated by quercetin in the liver.

\section{Confirmation with RT-qPCR}

The quercetin induced changes in expression of Cyp4a14, Cyp4a10, Acot3, Car, and Por that were identified by microarray analysis, were confirmed with RT-qPCR (Figure 6). Cyp4a14, Cyp4a10, Acot3 and Por were significantly up-regulated in the quercetin group, while the up regulation of Car followed the same trend, but did not reach significance.

\section{Discussion}

This study showed that chronic intake of quercetin in mice lowered serum lipid levels which are risk factors for CVD.
Microarray analysis indicated that hepatic genes involved in lipid metabolism, in particular in $\omega$-oxidation of fatty acids, could be responsible for these quercetin-induced effects.

Other studies have also observed that supplementation of quercetin to a high-fat diet decreases serum FFA and/or TG levels in mice $[10,11,12]$. However, these circulating FFA and TG levels were measured with commercial enzymatic assays, which have recently been found to be sensitive to interference of quercetin and its major metabolite quercetin-3-O-glucuronide, resulting in apparently incorrect lower detected levels [13]. Here, besides these enzymatic assays, we also used two independent analytical methods for quantification of serum lipid profiles; GC and ${ }^{1} \mathrm{H}$ NMR techniques. The observed effect of quercetin on lipid levels measured with the enzymatic FFA and TG assays (FFA - 13\% and TG $-27 \%$ ) was higher than measured with the two analytical techniques (GC: total fatty acids $-7 \%$ and ${ }^{1} \mathrm{H}$ NMR: FFA $-2 \%$, TG $-14 \%)$. This confirms interference of quercetin in the enzyme based assays [13] in the physiological range of quercetin exposure and as a consequence overestimate the lipid lowering effect of quercetin. Nevertheless, with GG and ${ }^{1} \mathrm{H}$ NMR a significant reduction in serum lipid levels was found, proving that lipid lowering is a real biological effect of quercetin. The GG data revealed that the specific serum fatty acids palmitic acid (16:0), oleic acid (18:1(n-9)) and linoleic acid (18:2(n-6)), originating from total lipids, were all significantly decreased in the quercetin-fed mice. Moreover, with ${ }^{1} \mathrm{H}$ NMR, serum lipids were measured separately, which revealed that serum TG levels of the quercetin group were significantly decreased, while total FFA, cholesterol and phospholipid levels remained unchanged. This indicates that the decreased levels of palmitic acid (16:0), oleic acid (18:1(n-9)) and linoleic acid (18:2(n-6)) found by GC originated from TG. Moreover, the ${ }^{1} \mathrm{H}$ NMR data showed unchanged levels of total FFA and increased levels of PUFA in the serum of the mice on the quercetin diet, which indicate a shift from saturated fatty acids to PUFA, which are known as the more healthy fatty acids. Together, these data proved that quercetin significantly reduced serum lipid levels and resulted in a more beneficial lipid profile.

The increased levels of PUFA and the decreased levels of saturated fatty acids cannot be fully explained by the microarray data. Genes involved in beta oxidation or specific desaturases were not differentially regulated by the quercetin diet.

There were no significant differences found in the serum phospholipid levels, while pathway analysis revealed phospholipid metabolism as a regulated pathway. However, based on gene expression it was not clear how phospholipid metabolism would be affected, since up as well down regulated genes were observed in different parts of this pathway, and a relative small number of genes of the total pathway was regulated. Therefore, it was concluded that this was not a crucial pathway in this study. Quercetin induced a decrease in relative liver weight in our study. This decrease cannot be explained by a decrease in hepatic lipid accumulation, because hepatic lipid levels were not affected by quercetin. Other studies $[11,12]$ have shown a decrease in lipid accumulation in liver upon dietary administration of quercetin and thus seem to be in contrast with our study. While a study with mulberry leaves, high in quercetin, did report unmodified lipid accumulation in the liver [23] and is thus in line with our data. The differences may be explained by the diets used in the different studies. We have used a mild-high-fat diet rich in unsaturated fatty acids, which did not result in extensive lipid accumulation in the liver, since the found hepatic lipid levels were in the same range as found for mice fed a normal-fat diet. The other studies that show a quercetin induced decrease in lipid accumulation used a high saturated fatty acid rich diet which induced lipid accumulation in 
the liver $[11,12]$. This suggests that quercetin may prevent lipid accumulation in the liver under adverse dietary conditions, but not with relatively healthy diets. In general, quercetin induced altered lipid metabolism on a mild-high-fat diet (our study), a normal-fat diet [10], and different high-fat diets [11,12]. Suggesting, that quercetin can affect lipid metabolism independent of the diet, although the impact of this effect can be different.

Using whole genome microarrays and confirmation by RTqPCR, we showed that quercetin up-regulates Cyp4a10, Cyp4a14, Cyp4a31, Acot3, Por, and, possibly Car. An integration of these genes into a single 'hepatic pathway' differentially expressed by quercetin treatment is proposed in Figure 7. Normally, fatty acids are mainly metabolized by $\beta$-oxidation first in peroxisomes (very long chain FFA) and subsequently in mitochondria (long, medium, and short chain FFA). Another type of fatty acid oxidation is $\omega-$ oxidation, which occurs in the endoplasmatic reticulum by members of the cytochrome $\mathrm{P} 4504 \mathrm{~A}$ family [24]. Omegaoxidation becomes more important during periods of increased influx of fatty acids into the liver, for example in our high-fat diet mice study, in obesity, and when the mitochondrial oxidation system is insufficient to metabolize fatty acids [25,26]. In these situations $\omega$-oxidation can prevent lipid toxicity [27]. Fatty acids oxidized by $\omega$-oxidation result in $\omega$-hydroxy fatty acids which are then dehydrogenated to a dicarboxylic acid in the cytosol. These dicarboxylic acids are further degraded by peroxisomal $\beta$ oxidation to shorter chain dicarboxylic fatty acids, which can be excreted in the urine, metabolized by the peroxisomal oxidation system to succinate and acetyl CoA, or completely oxidized after transport into the mitochondrial $\beta$-oxidation system [28]. A small increase of ketone bodies was found in the quercetin-fed mice suggesting an increase of $\beta$-oxidation (292.5 \pm 199.2 versus $185.6 \pm 118.1 \mu \mathrm{M}, \mathrm{p}=0.12$ ).

Acot3 was also up-regulated in our study, and the enzyme ACOT3 hydrolyses long-medium chain fatty acyl-CoA esters to FFA, and thus facilitate transport into peroxisomes. The FFA can subsequently be transported out of peroxisomes to mitochondria for further $\beta$-oxidation [29,30].

It has been described that, among others, palmitic acid (16:0) and oleic acid (18:1(n-9)) can be hydroxylated by CYP4A11, the human variant of murine Cyp4a10 [31]. This is especially consistent with the serum fatty acid profile obtained in the present study (Figure 2), where levels of palmitic acid (16:0) and oleic acid (18:1(n-9)) were significantly lower in the quercetin-fed mice. The significant up regulation of Cyp4a10, Cyp4a14, Cyp4a31 and Acot3 therefore explains the observed reduced serum levels for these specific fatty acids.

In humans, various polymorphisms are described in the genes of cytochromes $\mathrm{P} 450$ s and they can be considered as one of the major determinants of individual susceptibility to CVDs [32]. Allelic variations in CYP4A11 are suggested to result in an increased risk for hypertension [25,32]. Hypertension can be caused by increased serum lipid levels [6], which were decreased by quercetin in our study with concomitant up regulation of Cyp4a genes.

\section{References}

1. van't Veer P, Jansen MC, Klerk M, Kok FJ (2000) Fruits and vegetables in the prevention of cancer and cardiovascular disease. Public Health Nutr 3: 103-107.

2. Mink PJ, Scrafford CG, Barraj LM, Harnack L, Hong C-P, et al. (2007) Flavonoid intake and cardiovascular disease mortality: a prospective study in postmenopausal women. The American Journal of Clinical Nutrition 85: 895909.

3. Arts IC, Hollman PC (2005) Polyphenols and disease risk in epidemiologic studies. Am J Clin Nutr 81: 317S-325S.
The up regulation of the Cyp4a genes is consistent with the significant, 1.97 fold up regulation of Por by quercetin. POR is an enzyme that is required for electron transfer to cytochrome $\mathrm{P} 450$ enzymes and is therefore rate limiting for P450 enzymes. Deletion of the Por gene in a mouse model reduced hepatic $\mathrm{P} 450$ activity by more than 95\%. Moreover, hepatic Por knockout (Por-KO) mice showed decreased CYP4A protein levels, and an enlarged and fatty liver. Based on these observations, it was concluded that the P450 system plays a major role in regulating lipid homeostasis and hepatic lipid levels $[33,34]$. Two to three-fold more genes were significantly regulated when WT mice were exposed to quercetin compared to Por-KO mice. These genes were, among others, involved in fatty acid metabolism pathways. This suggests that hepatic POR mediates many of the biological effects of quercetin, including fatty acid metabolism [35]. These results underscores our data, which showed an up regulation of Por.

It is also suggested that $\mathrm{P} 450$ expression can be mediated via a GAR-dependent signaling pathway [36]. CAR is a transcription factor that is highly expressed in the liver. It is shown that ligand dependent activation of CAR increased lipid metabolism in rodents $[37,38]$ and it is also shown that this can lead to specifically increased expression of genes involved in $\omega$-oxidation [39]. Furthermore, exposure of quercetin to HepG2 cells transfected with CAR showed that CAR can be activated by quercetin $[40,41]$. Our data showed significant up regulation of Car $(\mathrm{FC}=1.37$, FDR adjusted $\mathrm{p}$-value $=0.005)$, which suggests that Car has an important role in quercetin mediated regulation of lipid metabolism.

This study used male mice, therefore caution is needed in translating these data to female mice. It is known that there are sex differences in the sensitivity to CAR activators and also Cyp4a genes can be under sex-dependent control $[42,43]$. In conclusion, quercetin can affect hepatic lipid metabolism, especially $\omega$ oxidation. This is shown by the up regulation of Cyp4a10, Cyp4a14, Cyp4a31, Acot3, Por and the transcription factor Car. These effects are associated with decreased corresponding circulating lipid levels, which may contribute to potential beneficial effects on CVD.

\section{Acknowledgments}

We thank Henk van der Kamp for his help with the dietary fatty acid composition determinations, Peter van Baarlen for his help by the microarray analysis with Ingenuity, and Lonneke Janssen Duijghuijsen for her help with the ketone bodies measurements.

\section{Author Contributions}

Conceived and designed the experiments: EFHvdH JK AB PGHH IMCMR EMvS. Performed the experiments: EFHvdH AB JJMV BS MB LH DV ET EMvS. Analyzed the data: EFHvdH JK JJMV EMvS. Contributed reagents/materials/analysis tools: JJMV ET. Wrote the paper: EFHvdH JK PCHH IMCMR EMvS.

4. Hertog MG, Feskens EJ, Hollman PC, Katan MB, Kromhout D (1993) Dietary antioxidant flavonoids and risk of coronary heart disease: the Zutphen Elderly Study. Lancet 342: 1007-1011.

5. Hollman PC, Geelen A, Kromhout D (2010) Dietary flavonol intake may lower stroke risk in men and women. J Nutr 140: 600-604.

6. Boden G (2008) Obesity and Free Fatty Acids. Endocrinology \& Metabolism Clinics of North America 37: 635-646.

7. Harchaoui KE, Visser ME, Kastelein JJ, Stroes ES, Dallinga-Thie GM (2009) Triglycerides and cardiovascular risk. Curr Cardiol Rev 5: 216-222. 
8. Jouven X, Charles MA, Desnos M, Ducimetiere P (2001) Circulating nonesterified fatty acid level as a predictive risk factor for sudden death in the population. Circulation 104: 756-761.

9. Pilz S, Scharnagl H, Tiran B, Seelhorst U, Wellnitz B, et al. (2006) Free Fatty Acids Are Independently Associated with All-Cause and Cardiovascular Mortality in Subjects with Coronary Artery Disease. J Clin Endocrinol Metab 91: 2542-2547.

10. de Boer VC, van Schothorst EM, Dihal AA, van der Woude H, Arts IC, et al. (2006) Chronic quercetin exposure affects fatty acid catabolism in rat lung. Cell Mol Life Sci 63: 2847-2858.

11. Jung CH, Cho I, Ahn J, Jeon TI, Ha TY (2012) Quercetin Reduces High-Fat Diet-Induced Fat Accumulation in the Liver by Regulating Lipid Metabolism Genes. Phytother Res.

12. Kobori M, Masumoto S, Akimoto Y, Oike H (2011) Chronic dietary intake of quercetin alleviates hepatic fat accumulation associated with consumption of a Western-style diet in C57/BL6J mice. Mol Nutr Food Res 55: 530-540.

13. Hoek-van den Hil EF, Beekmann K, Keijer J, Hollman PC, Rietjens IM, et al. (2012) Interference of flavonoids with enzymatic assays for the determination of free fatty acid and triglyceride levels. Anal Bioanal Chem 402: 1389-1392.

14. Baum SJ, Kris-Etherton PM, Willett WC, Lichtenstein AH, Rudel LL, et al. (2012) Fatty acids in cardiovascular health and disease: A comprehensive update. J Clin Lipidol 6: 216-234.

15. Tukiainen T, Tynkkynen T, Makinen VP, Jylanki P, Kangas A, et al. (2008) A multi-metabolite analysis of serum by $1 \mathrm{H}$ NMR spectroscopy: early systemic signs of Alzheimer's disease. Biochem Biophys Res Commun 375: 356-361.

16. Vinaixa M, Rodriguez MA, Rull A, Beltran R, Blade C, et al. (2010) Metabolomic assessment of the effect of dietary cholesterol in the progressive development of fatty liver disease. J Proteome Res 9: 2527-2538.

17. Fiorini RN, Kirtz J, Periyasamy B, Evans Z, Haines JK, et al. (2004) Development of an unbiased method for the estimation of liver steatosis. Clin Transplant 18: 700-706.

18. Folch J, Lees M, Sloane Stanley GH (1957) A simple method for the isolation and purification of total lipides from animal tissues. J Biol Chem 226: 497-509.

19. Carlson LA (1985) Extraction of lipids from human whole serum and lipoproteins and from rat liver tissue with methylene chloride-methanol: a comparison with extraction with chloroform-methanol. Clin Chim Acta 149: 89-93.

20. van Schothorst EM, Pagmantidis V, de Boer VC, Hesketh J, Keijer J (2007) Assessment of reducing RNA input for Agilent oligo microarrays. Anal Biochem 363: 315-317.

21. Pellis L, Franssen-van Hal NL, Burema J, Keijer J (2003) The intraclass correlation coefficient applied for evaluation of data correction, labeling methods, and rectal biopsy sampling in DNA microarray experiments. Physiol Genomics 16: 99-106.

22. Hochberg Y, Benjamini Y (1990) More powerful procedures for multiple significance testing. Stat Med 9: 811-818.

23. Kobayashi Y, Miyazawa M, Kamei A, Abe K, Kojima T (2010) Ameliorative effects of mulberry (Morus alba L.) leaves on hyperlipidemia in rats fed a high-fat diet: induction of fatty acid oxidation, inhibition of lipogenesis, and suppression of oxidative stress. Biosci Biotechnol Biochem 74: 2385-2395.

24. Lavoie JM, Gauthier MS (2006) Regulation of fat metabolism in the liver: link to non-alcoholic hepatic steatosis and impact of physical exercise. Cell Mol Life Sci 63: 1393-1409.

25. Hsu MH, Savas U, Griffin KJ, Johnson EF (2007) Human cytochrome p450 family 4 enzymes: function, genetic variation and regulation. Drug Metab Rev 39: 515-538.

26. Reddy JK, Rao MS (2006) Lipid metabolism and liver inflammation. II. Fatty liver disease and fatty acid oxidation. Am J Physiol Gastrointest Liver Physiol 290: G852-858.
27. Hardwick JP, Osei-Hyiaman D, Wiland H, Abdelmegeed MA, Song BJ (2009) PPAR/RXR Regulation of Fatty Acid Metabolism and Fatty Acid omegaHydroxylase (CYP4) Isozymes: Implications for Prevention of Lipotoxicity in Fatty Liver Disease. PPAR Res 2009: 952734.

28. Hardwick JP (2008) Cytochrome P450 omega hydroxylase (CYP4) function in fatty acid metabolism and metabolic diseases. Biochem Pharmacol 75: 22632275.

29. Hunt MC, Yamada J, Maltais LJ, Wright MW, Podesta EJ, et al. (2005) A revised nomenclature for mammalian acyl-CoA thioesterases/hydrolases. J Lipid Res 46: 2029-2032.

30. Kirkby B, Roman N, Kobe B, Kellie S, Forwood JK (2010) Functional and structural properties of mammalian acyl-coenzyme A thioesterases. Prog Lipid Res 49: 366-377.

31. Hoch U, Zhang Z, Kroetz DL, Ortiz de Montellano PR (2000) Structural determination of the substrate specificities and regioselectivities of the rat and human fatty acid omega-hydroxylases. Arch Biochem Biophys 373: 63-71.

32. Zordoky BN, El-Kadi AO (2010) Effect of cytochrome P450 polymorphism on arachidonic acid metabolism and their impact on cardiovascular diseases. Pharmacol Ther 125: 446-463.

33. Henderson CJ, Otto DM, Carrie D, Magnuson MA, McLaren AW, et al. (2003) Inactivation of the hepatic cytochrome P450 system by conditional deletion of hepatic cytochrome P450 reductase. J Biol Chem 278: 13480-13486.

34. Mutch DM, Klocke B, Morrison P, Murray CA, Henderson CJ, et al. (2007) The disruption of hepatic cytochrome p450 reductase alters mouse lipid metabolism. J Proteome Res 6: 3976-3984.

35. Mutch DM, Crespy V, Clough J, Henderson CJ, Lariani S, et al. (2006) Hepatic cytochrome P-450 reductase-null mice show reduced transcriptional response to quercetin and reveal physiological homeostasis between jejunum and liver. Am J Physiol Gastrointest Liver Physiol 291: G63-72.

36. Finn RD, Henderson CJ, Scott CL, Wolf CR (2009) Unsaturated fatty acid regulation of cytochrome $\mathrm{P} 450$ expression via a CAR-dependent pathway. Biochem J 417: 43-54.

37. Dong B, Saha PK, Huang W, Chen W, Abu-Elheiga LA, et al. (2009) Activation of nuclear receptor CAR ameliorates diabetes and fatty liver disease. Proc Natl Acad Sci U S A 106: 18831-18836.

38. Venkatesan N, Davidson MB, Simsolo RB, Kern PA (1994) Phenobarbital treatment enhances insulin-mediated glucose metabolism and improves lipid metabolism in the diabetic rat. Metabolism 43: 348-356.

39. Baskin-Bey ES, Anan A, Isomoto H, Bronk SF, Gores GJ (2007) Constitutive androstane receptor agonist, TCPOBOP, attenuates steatohepatitis in the methionine choline-deficient diet-fed mouse. World J Gastroenterol 13: 56355641 .

40. Li L, Stanton JD, Tolson AH, Luo Y, Wang H (2009) Bioactive terpenoids and flavonoids from Ginkgo biloba extract induce the expression of hepatic drugmetabolizing enzymes through pregnane $\mathrm{X}$ receptor, constitutive androstane receptor, and aryl hydrocarbon receptor-mediated pathways. Pharm Res 26: 872-882.

41. Yao R, Yasuoka A, Kamei A, Kitagawa Y, Tateishi N, et al. (2010) Dietary flavonoids activate the constitutive androstane receptor (CAR). J Agric Food Chem 58: 2168-2173.

42. Hernandez JP, Mota LC, Baldwin WS (2009) Activation of CAR and PXR by Dietary, Environmental and Occupational Chemicals Alters Drug Metabolism, Intermediary Metabolism, and Cell Proliferation. Curr Pharmacogenomics Person Med 7: 81-105.

43. Sundseth SS, Waxman DJ (1992) Sex-dependent expression and clofibrate inducibility of cytochrome P450 4A fatty acid omega-hydroxylases. Male specificity of liver and kidney CYP4A2 mRNA and tissue-specific regulation by growth hormone and testosterone. J Biol Chem 267: 3915-3921. 